\title{
Keragaan Tujuh Varietas Bawang Merah (Allium cepa L. Aggregatum group) TSS (True Shallot Seed)
}

\author{
Performance of Seven Varieties of Shallot (Allium cepa L. Aggregatum group) TSS (True Shallot $\underline{\text { Seed) }}$ \\ Tika Anisa Padar Wati ${ }^{1}$, Sobir ${ }^{1,2^{*}}$
}

\begin{abstract}
${ }^{1}$ Departemen Agronomi dan Hortikultura, Fakultas Pertanian, Institut Pertanian Bogor (Bogor Agricultural University), Jalan Meranti, Kampus IPB Darmaga, Bogor 16680, Indonesia.

${ }^{2}$ Pusat Kajian Hortikultura Tropika, Lembaga Penelitian dan Pengabdian kepada Masyarakat Institut Pertanian Bogor, Jl. Raya Pajajaran, Kampus IPB Baranangsiang, Bogor, Indonesia
\end{abstract}

Diterima 26 September 2018/Disetujui 22 Oktober 2018

\begin{abstract}
True Shallot Seed (TSS) of shallot is shallot seed origin as solution of seed availability problem. Generally, farmers still use bulb seed for shallot production. This is because the aspect of shallot cultivation using TSS seed is still to be reviewed. The aims of this research is get information of performance some varieties of TSS shallot compared to bulb seed of Bima Brebes. This research was conducted in the experimental field of Pasir Sarongge IPB, Cianjur in a Randomize Complete Block Design Group by one factor for with three replication. TSS varieties used Bima Brebes (TSS), Tuk tuk, Pikatan, Tajuk, BM 8705, Sanren, and Manjung compared to bulb seed of Bima Brebes. The result showed variability of color and bulb characters on TSS shallot. Variety of Sanren has leaf length, pseudostems diameter, leaf diameter, and number cloves of clump are higher than Bima both of TSS and bulb seed. The dry weight of clump variety for Sanren, Manjung, and BM 8705 showed not significant to bulb seed of Bima Brebes.
\end{abstract}

Keywords : bulb seed, seed availability, variability

\section{ABSTRAK}

Bawang merah TSS (True Shallot Seed) merupakan bawang merah asal biji sebagai solusi permasalahan ketersediaan benih. Umumnya petani masih menggunakan benih asal umbi untuk produksi bawang merah. Hal ini dikarenakan aspek budidaya bawang merah TSS ini masih harus dikaji ulang. Penelitian ini bertujuan untuk memperoleh informasi keragaan beberapa varietas bawang merah dari benih TSS dibandingkan dengan varietas Bima Brebes, benih dari umbi. Penelitian ini dilaksanakan di Kebun Percobaan Pasir Sarongge IPB, Kabupaten Cianjur. Pelaksanan penelitian menggunakan Rancangan Kelompok Lengkap Teracak (RKLT) dengan satu faktor yaitu varietas dengan 3 ulangan. Tujuh varietas yang digunakan yaitu Bima Brebes (TSS), Tuk tuk, Pikatan, Tajuk, BM 8705, Sanren, dan Manjung. Varietas pembanding dari ketujuh varietas tersebut yaitu Bima Brebes (benih asal umbi). Hasil penelitian ini adalah terdapat keragaman pada karakter warna dan bentuk umbi pada tujuh varietas bawang merah TSS. Varietas Sanren mempunyai nilai panjang daun, diameter batang semu, diameter daun, dan jumlah daun per batang semu yang lebih tinggi dibandingkan dengan varietas pembanding (Bima, benih dari umbi). Berdasarkan nilai bobot kering per rumpun pada rerata varietas, varietas Sanren, Manjung, dan BM 8705 tidak berbeda nyata dengan varietas pembanding (Bima, benih dari umbi).

Kata kunci : benih umbi, keragaman, ketersediaan benih

\section{PENDAHULUAN}

Bawang merah merupakan sayuran yang umum dibudidayakan oleh petani di Indonesia menggunakan benih dari umbi (Anwar et. al., 2005). Menurut Pusdatin (2016) pertumbuhan produksi bawang merah tahun 2010-2015 sekitar $3.93 \%$ per tahun. Kegiatan produksi bawang merah

\footnotetext{
* Penulis untuk korespondensi. e-mail: ridwanisobir@gmail.com
}

mempunyai beberapa permasalahan. Menurut Prayudi et al., (2015) salah satu permasalahan kegiatan produksi bawang merah adalah ketersediaan benih. Basuki (2009) menyatakan bahwa penyediaan benih membutuhkan biaya yang cukup tinggi, yaitu biaya distribusi dan penyimpanan benih. Kesulitan distribusi benih juga menjadi permasalahan dalam kegiatan produksi bawang merah (Rosliani, 2013).

Umumnya petani Indonesia menggunakan benih asal umbi untuk kegiatan produksi bawang merah (Pangestuti dan Sulistyaningsih, 2011). Benih asal umbi yang umumnya digunakan untuk produksi bawang merah memiliki beberapa 
kelemahan. Pangestuti dan Sulistyaningsih (2011) dan Prayudi et al. (2015) menyatakan bahwa kelemahan benih umbi yaitu daya simpan benih umbi rendah (1-4 bulan), kebutuhan benih tinggi (1.5 ton per ha). Menurut Firmansyah et al. (2014) bahwa benih asal umbi mudah terkontaminasi penyakit tular umbi. Produktivitas benih umbi bawang merah relatif rendah, yaitu sekitar 17.1 ton per ha (Prayudi et al., 2015). Sehingga keuntungan yang diperoleh rendah, yaitu sekitar 47-57 juta rupiah per ha (Basuki, 2009).

Benih TSS (True Shallot Seed) bawang merah merupakan benih bawang merah asal biji sebagai solusi permasalahan ketersediaan benih. Benih TSS bawang merah memiliki beberapa kelebihan. Pangestuti Sulistyaningsih (2011) menyatakan bahwa penyimpanan benih TSS relatif mudah dan tidak membutuhkan ruang luas, serta jarang terkontaminasi virus dan penyakit tular benih. Kelebihan benih TSS menurut Prayudi et al. (2015) yaitu kebutuhan tanam sedikit, daya simpan benih tinggi, dan sifat keragaman hasil panen rendah. Produktivitas benih TSS bawang merah relatif tinggi, yaitu sekitar 36.2-42.5 ton per ha.

Teknologi TSS layak dikembangkan karena dapat memberikan keuntungan usaha tani yang lebih besar dibandingkan penggunaan benih bawang merah dalam bentuk umbi (Basuki, 2009). Menurut Basuki (2009) bahwa penggunaan benih TSS menurunkan biaya variabel sekitar 10-29 juta per ha. Namun, aspek budidaya bawang merah TSS harus dikaji ulang, seperti pemilihan lokasi dan penggunaan screenhouse (Puspitasari et al., 2016). Basuki (2009) menyarankan bahwa penelitian lanjutan perlu dilakukan untuk mengetahui aspek budidaya benih TSS bawang merah. Oleh karena itu, penelitian ini dilakukan untuk memperoleh informasi keragaan beberapa varietas bawang merah dari benih TSS dibandingkan dengan varietas Bima Brebes (benih dari umbi).

\section{BAHAN DAN METODE}

Percobaan dilaksanakan di Kebun Percobaan Pasir Sarongge IPB, Cianjur, Jawa Barat di dalam rumah plastik. Percobaan dilaksanakan pada bulan Desember 2017 hingga Mei 2018. Kebun Percobaan Pasir Sarongge merupakan kebun milik IPB yang berada pada ketinggian sekitar $1000 \mathrm{~m}$ dpl. Jenis tanah di kebun ini yaitu tanah andisol. Data agroklimat tersebut tercantum dalam website resmi University Farm (UF) Institut Pertanian Bogor. Data iklim pada bulan Desember 2017-Maret 2018 diperoleh dari Badan Meteorologi, Klimatologi, dan Geofisika (BMKG) Stasiun Bogor dan Pos hujan Pacet (2018).

Bahan tanaman yang digunakan adalah True Shallot Seed (TSS) berupa benih bawang merah dari 7 varietas yaitu Bima Brebes, Tuk tuk, Pikatan, Tajuk, BM 8705, Sanren, dan Manjung yang dibandingkan dengan benih berupa umbi dari varietas Bima Brebes (benih dari umbi). Bahan-bahan lain yang digunakan adalah media semai, pupuk kandang, arang sekam, pupuk NPK Phonska, SP-36, KCl, NPK (16-16-16), ZA, NPK Grower (15-9-20), insektisida, dan fungisida. Alat yang digunakan yaitu baki semai, alat tanam, jangka sorong, RHS color chart, timbangan digital, dan alat dokumentasi.
Percobaan dilakukan menggunakan Rancangan Kelompok Lengkap Teracak (RKLT) satu faktor yaitu varietas. Perlakuan berupa 7 varietas bawang merah TSS dengan 1 varietas bawang merah (benih dari umbi). Setiap perlakuan dilakukan pengulangan sebanyak tiga ulangan, sehingga dihasilkan 24 satuan percobaan. Setiap satuan percobaan terdiri atas 50 tanaman sehingga jumlah tanaman seluruh satuan percobaan sebanyak 1,200 tanaman. Data yang diperoleh diolah menggunakan uji $\mathrm{F}$ pada taraf nyata $5 \%$. Apabila perlakuan berpengaruh nyata, dilakukan uji lanjut Beda Nayata Jujur (BNJ) menggunakan perangkat lunak SAS. Analisis korelasi dilakukan untuk mengetahui pengaruh antar peubah yang diamati menggunakan perangkat lunak Minitab.

\section{Pelaksanaan kegiatan}

Benih TSS bawang merah direndam dalam larutan PGPR dengan dosis $10 \mathrm{~g} \mathrm{~L}^{-1}$ selama 10 menit. Benih disemaikan pada baki semaian menggunakan media tanam campuran tanah, pupuk kandang, dan arang sekam (1:1:1). Pemberian pupuk organik cair dosis 1.5-2.0 $\mathrm{g} \mathrm{L}^{-1}$ air disiramkan pada umur 17 hari setelah semai (HSS). Pengendalian dilakukan untuk melindungi bibit dari serangan penyakit rebah oleh Pytium sp dilakukan pada minggu ke-3 setelah semai di persemaian menggunakan fungisida bahan aktif iprodion $50 \%$ dosis $2 \mathrm{~g} \mathrm{~L}^{-1}$.

Petak percobaan berupa bak tanam berukuran $2 \mathrm{~m} \mathrm{x}$ $1 \mathrm{~m}$ dan bersungkup plastik kemudian diisi media tanam campuran tanah, arang sekam, dan pupuk kandang (2:1:1). Pupuk dasar yang digunakan yaitu pupuk kandang dosis 20 ton $\mathrm{ha}^{-1}$ (4 $\mathrm{kg}$ per bak tanam), pupuk SP36 dosis $200 \mathrm{~kg} \mathrm{ha}^{-1}$ (40 g per bak tanam), pupuk Phonska $450 \mathrm{~kg}$ ha- (90 g per bak tanam), dan KCL dengan dosis $150 \mathrm{~kg} \mathrm{ha}^{-1}$ (30 g per bak tanam).

Pindah tanam dilakukan pada umur tanaman \pm 40 HSS, menggunakan 1 atau 2 bibit per lubang tanam, dengan jarak tanam $10 \mathrm{~cm}$ x $10 \mathrm{~cm}$. Pemupukan dilakukan sebanyak tiga kali. Pemupukan susulan pertama yaitu aplikasi pupuk NPK Mutiara dosis $400 \mathrm{~kg} \mathrm{ha}^{-1}$ (20 g per satuan percobaan) dan ZA dosis $200 \mathrm{~kg} \mathrm{ha}^{-1}$ (10 g per satuan percobaan), yang dilakukan pada saat tanaman berumur 4 minggu setelah tanam (MST). Pemupukan susulan kedua dilakukan pada umur 45 hari setelah tanam(HST). Pemupukan menggunakan pupuk NPK (15-9-20) Hydrokompleks (Grower) dosis $400 \mathrm{~kg} \mathrm{ha}^{-1}$ (20 g per satuan percobaan). Rekomendasi penggunaan pupuk, dosis pemupukan, dan cara pemupukan berdasarkan Panduan Teknis Budidaya Bawang Merah TSS oleh Kementrian Pertanian (2016).

Penyiraman dilakukan dua kali sehari (pagi dan sore) pada tanaman umur 0-7 HST. dan satu kali sehari (pagi) pada umur 8-28 HST. Penyiraman dilakukan dua hari sekali (pagi) pada umur tanaman 29 HST hingga sebelum panen. Pengendalian hama dan penyakit dilakukan mulai \pm 6 MST menggunakan fungisida dan insektisida. Fungisida yang digunakan yaitu Sindazeb 80 WP bahan aktif mankozeb $80 \%$ dosis $2 \mathrm{~g} \mathrm{~L}^{-1}$ untuk pengendalian penyakit bercak ungu atau trotol oleh cendawan. Alternaria porri (Ell.) Cif.. 
Insektisida yang digunakan yaitu Dursban 200 EC bahan aktif klorpirifos $200 \mathrm{~g} \mathrm{~L}^{-1}$ dengan dosis aplikasi 1,5 $\mathrm{ml} \mathrm{L}^{-1}$ untuk pengendalian hama ulat bawang (Spodoptera Exigua) dan ulat grayak ( $S$. litura). Panen dilakukan setelah daun mulai menguning dengan persentase mencapai $50 \%$, bagian atas tanaman mulai rebah, pangkal daun kempes, sebagian besar umbi tersembul di atas permukaan tanah, dan adanya warna merah khas dan terbentuk warna merah tua atau merah keunguan pada umbinya atau umur 105-110 HST dan dikeringkan selama 7-12 hari.

Pengamatan berdasarkan panduan pelaksanaan uji kebaruan, keunikan, keseragaman dan kestabilan (PPVTPP, 2016). Karakter kualitatif yang diamati pada 10 tanaman contoh antara lain tingkat kepatahan daun, keberadaan lapisan lilin pada daun, dan kerapatan daun diamati pada saat umur optimum tanaman (77 HST), warna dasar kulit umbi kering, corak warna pada kulit umbi kering, warna daging umbi, bentuk penampang membujur umbi, bentuk ujung dan pangkal umbi, serta tingkat melekatnya kulit umbi kering. Karakter kuantitatif yang diamati pada tinggi tanaman $(\mathrm{cm})$, panjang daun $(\mathrm{cm})$, diameter daun $(\mathrm{cm})$, panjang batang semu $(\mathrm{cm})$, diameter batang semu $(\mathrm{cm})$, dan jumlah daun setiap batang semu diamati pada saat umur optimum tanaman (11 MST), jumlah siung per rumpun, bobot basah per rumpun (g), bobot kering per rumpun $(\mathrm{g})$, tinggi umbi $(\mathrm{cm})$, diameter umbi $(\mathrm{mm})$, rasio tinggi/ diameter, posisi diameter maksimal $(\mathrm{cm})$, lebar leher umbi (mm), dan ketebalan kulit umbi kering ( $\mathrm{mm}$ ) diamati setelah umbi dipanen dan dikeringkan.

\section{HASIL DAN PEMBAHASAN}

\section{Kondisi Umum}

Data curah hujan rata-rata $320.9 \mathrm{~mm}$ bulan $^{-1}$, suhu ratarata berkisar $21{ }^{\circ} \mathrm{C}-22{ }^{\circ} \mathrm{C}$, dan kelemaban rata-rata sebesar 80.05\% (BMKG, 2017). Menurut Sumarni dan Hidayat (2005) bahwa tanaman bawang merah dapat membentuk umbi di daerah dengan suhu udara rata-rata $22{ }^{\circ} \mathrm{C}$, tetapi umbi yang dihasilkan tidak sebaik di daerah dengan suhu udara lebih panas. Tanaman bawang merah masih dapat tumbuh dan berumbi di dataran tinggi, tetapi umur tanamnya menjadi lebih lama 0.5-1 bulan.

Benih TSS mulai berkecambah pada 7 HSS dengan daya berkecambah (DB) sekitar 80- $95 \%$. Urutan kecepatan berkecambah yaitu varietas Bima, BM 8705, Sanren, Manjung, Tuk tuk, Pikatan, dan Tajuk. Perbedaan daya tumbuh biji bawang merah akibat perbedaan struktur biji. Varietas dengan struktur biji berkulit biji (testa) yang tebal menghambat pertumbuhan tetapi biji yang berembrio sempurna memiliki pertumbuhan lebih baik (Wulandari et. al., 2014). Persentase tumbuh tanaman saat setelah pindah tanam hingga sebelum panen mencapai 98-100\%. Serangan hama dan penyakit saat setelah pindah tanam terjadi mulai 4 MST (Minggu Setelah Tanam). Penyakit yang menyerang yaitu layu fusarium dan bercak ungu (Alternaria porii) (Gambar 9). Pengendalian dilakukan dengan penyempotan fungisida dan insektisida setiap tujuh hari sekali.
Hama yang menyerang hampir semua varietas yaitu ulat bawang dan ulat grayak. Gejala serangan ulat grayak yang tampak pada tanaman yaitu daun layu dan kemudian tanaman mati, karena akar tanaman. Pertumbuhan bunga pada tanaman mulai muncul pada minggu ke- 8 setelah tanam. Awalnya pembungaan pada varietas Bima Brebes benih umbi, kemudian diikuti oleh varietas BM 8705, Sanren, Bima Brebes benih TSS, Manjung, Tajuk, Tuk tuk, dan Pikatan. Presentase pembungaan terbanyak pada varietas Sanren yaitu sekitar $26.67 \%$. Pertumbuhan bunga terjadi diduga dipengaruhi oleh genetik dan generasi varietas yang ditanam. Benih TSS dihasilkan oleh tanaman yang mudah berbunga, sehingga terdapat kemungkinan bahwa benih yang dihasilkan juga mudah berbunga. Beberapa faktor lain yang dapat mempengaruhi terjadinya pembungaan pada tanaman bawang merah yaitu faktor penyimpanan benih dan lingkungan tumbuh. Pembungaan bawang merah juga dapat dipengaruhi oleh ketinggian tempat penanaman. Menurut Hilman et. al. (2014) bahwa pembungaan bawang merah di dataran tinggi mencapai 2.5 -3 kali lipat daripada di dataran rendah.

\section{Karakter Kualitatif}

\section{Karakter Kualitatif pada Tanaman Bawang Merah}

Hasil pengamatan menunjukkan bahwa varietas Bima Brebes benih umbi sebagai varietas pembanding memiliki tingkat kepatahan daun yang kuat, kerapatan daun yang jarang, dan keberadaan lapisan lilin yang sedang (Tabel 1). Tingkat kepatahan daun pada varietas Sanren juga kuat, namun kerapatan daunnya jarang dan keberadaan lapisan lilinnya lemah.

\section{Karakter Kualitatif pada Umbi Bawang Merah}

Hasil pengamatan pada umbi bawang merah pada karakter kualitatif menunjukkan adanya keragaman (Tabel 2). Warna dasar kulit umbi kering menunjukkan warna dominan pada kulit umbi kering. Persamaan warna pada karakter warna dasar kulit umbi kering yaitu pada varietas Tuk Tuk dengan Manjung dan varietas Pikatan dengan BM 8705 (Tabel 2). Varietas Tuk tuk, Tajuk, dan Manjung memiliki corak warna kulit umbi kering yang sama. Persamaan warna pada warna daging umbi terjadi pada varietas Pikatan dengan Manjung dan antara varietas Tuk tuk, Tajuk, BM 8705, dan Sanren. Keragaman pada karakter bentuk umbi beberapa varietas bawang merah menunjukkan bahwa keragaan bentuk umbi tiap varietas berbeda. Varietas Bima (umbi) memiliki bentuk penampang membujur umbi yang berbeda dengan tujuh varietas bawang merah lainnya (Tabel 3). Lemahnya tingkat melekatnya kulit umbi kering pada semua varietas menunjukkan bahwa kulit umbi kering mudah terlepas dari umbinya. Keragaman warna dan bentuk umbi bawang merah yang dihasilkan dapat mempengaruhi ketertarikan konsumen terhadap keragaan umbi bawang merah. Bawang merah dengan warna merah, umbinya padat, rasanya pedas, aromanya wangi jika digoreng, dan 
bentuknya lonjong lebih menarik dan disukai oleh konsumen (Sumarni dan Hidayat, 2005). Adanya kemungkinan dua varietas lebih disukai konsumen daripada varietas laiannya, karena warna dasar kulit umbi kering varietas Tuk tuk dan Manjung yaitu strong red (merah).

\section{Karakter Kuantitatif}

\section{Analisis Ragam}

Rekapitulasi hasil analisis ragam pada karakterkarakter kuantitatif menunjukkan bahwa perbedaan varietas memberikan pengaruh yang nyata (Tabel 4). Pengaruh yang nyata tersebut menunjukkan bahwa adanya keragaman karakter kuantitif pada masing-masing varietas bawang merah TSS yang diuji. Keragaman tersebut menerangkan bahwa setiap varietas memberikan respon yang berbeda pada kondisi lingkungan yang sama.

Nilai koefisien keragaman (KK) pada karakter yang diamati berkisar 4.71-23.17 \%. Adanya keragaman diduga dipengaruhi oleh lingkungan, walaupun untuk semua varietas ditanam pada kondisi lingkungan yang sama. Menurut Sumarni dan Rosliani (2010) bahwa proses pertumbuhan dan bobot hasil umbi bawang merah dapat dipengaruhi oleh lingkungan, yaitu adanya naungan dan kerapatan tanam.

Tabel 1. Hasil pengamatan karakter vegetatif bawang merah

\begin{tabular}{lccc}
\hline \multicolumn{1}{c}{ Varietas } & Tingkat kepatahan daun & Kerapatan daun & Keberadaan lapisan lilin \\
\hline Bima (umbi) & Kuat & Jarang & Sedang \\
Bima (TSS) & Sedang & Jarang & Lemah \\
Pikatan & Sedangg & Jarang & Lemah \\
Tuk tuk & Sedang & Jarang & Lemah \\
Tajuk & Sedang & Jarang & Lemah \\
BM 8705 & Sedang & Jarang & Lemah \\
Sanren & Kuat & Jarang & Lemah \\
Manjung & Sedang & Jarang & Lemah \\
\hline
\end{tabular}

Tabel 2. Hasil pengamatan karakter warna umbi bawang merah

\begin{tabular}{lccc}
\hline \multicolumn{1}{c}{ Varietas } & Warna dasar kulit kering & $\begin{array}{c}\text { umbi Corak warna pada kulit } \\
\text { umbi kering }\end{array}$ & Warna daging umbi \\
\hline Bima (umbi) & Light pink & Moderate yellowish pink & Very light purple \\
Bima (TSS) & Strong pink & Deep yellowish pink & Light reddish purple \\
Pikatan & Deep pink & Strong red & Deep reddish purple \\
Tuk tuk & Strong red & Deep pink & Light purple \\
Tajuk & Light yellowish pink & Deep pink & Light purple \\
BM 8705 & Deep pink & Moderate yellowish pink & Light purple \\
Sanren & Light yellowish pink & Light yellowish pink & Light purple \\
Manjung & Strong red & Deep pink & Deep reddish puple \\
\hline
\end{tabular}

Tabel 3. Hasil pengamatan karakter bentuk dan kulit umbi bawang merah

\begin{tabular}{lcccc}
\hline \multicolumn{1}{c}{ Varietas } & $\begin{array}{c}\text { Bentuk penampang } \\
\text { membujur umbi }\end{array}$ & Bentuk ujung umbi & Bentuk pangkal umbi & $\begin{array}{c}\text { Tingkat } \\
\text { kulit umbi kering }\end{array}$ \\
\hline Bima (umbi) & Bulat telur terbalik lebar & Bulat & Bulat & Lemah \\
Bima (TSS) & Elips melintang sedang & Agak naik & Rata & Lemah \\
Pikatan & Elips melintang sedang & Agak naik & Rata & Lemah \\
Tuk tuk & Elips melintang sedang & Bulat & Rata & Lemah \\
Tajuk & Elips melintang sedang & Bulat & Rata & Lemah \\
BM 8705 & Elips melintang sedang & Bulat & Rata & Lemah \\
Sanren & Elips melintang sedang & Agak naik & Rata & Lemah \\
Manjung & Elips melintang sedang & Agak naik & Rata & Lemah \\
\hline
\end{tabular}


Tinggi Tanaman, Panjang Batang Semu, Diameter Batang Semu, Jumlah Daun per Batang Semu, Panjang Daun, dan Diameter Daun

Nilai tengah hasil pengamatan tinggi tanaman dari tujuh varietas yang diuji berkisar $38.1-53.7 \mathrm{~cm}$ (Tabel 5). Nilai tengah dari varietas pembanding (Bima Brebes) sebesar 43.3 - $44.8 \mathrm{~cm}$. Varietas BM 8705, Sanren, dan Manjung memiliki nilai tengah tinggi tanaman yang tidak berbeda nyata dengan varietas pembanding. Varietas Pikatan memiliki nilai tengah tinggi tanaman tidak berbeda nyata dengan varietas pembanding.

Hasil pengamatan panjang batang semu menunjukkan bahwa ketujuh varietas TSS yang diuji memiliki nilai tengah lebih rendah dibandingkan dengan varietas pembanding (benih dari umbi) (Tabel 5). Nilai tengah varietas Bima (umbi) paling tinggi, yaitu $8.0 \mathrm{~cm}$. Varietas Bima (TSS) bernilai tengah tidak berbeda nyata dengan varietas Pikatan, Tuk tuk, dan Tajuk. Nilai tengah varietas BM 8705 dan Sanren tidak berbeda nyata dengan varietas Bima (umbi).

Nilai tengah hasil pengamatan diameter batang semu ketujuh varietas yang diuji lebih unggul dibandingkan varietas pembanding (Tabel 5). Hal ini dikarenakan nilai tengah varietas Bima (umbi) terendah, yaitu $5.11 \mathrm{~mm}$ dan tidak berbeda nyata dengan varietas Bima (TSS), Tuk tuk, dan Tajuk. Varietas Sanren memiliki nilai tengah diameter batang semu yang berbeda nyata dengan varietas Bima (umbi). Hasil pengamatan jumlah daun per batang semu menunjukkan bahwa nilai tengah varietas Sanren tertinggi. Varietas Bima (umbi) berbeda nyata dengan varietas Sanren

Tabel 4. Rekapitulasi hasil analisis ragam karakter - karakter kuantitatif

\begin{tabular}{rlcc}
\hline No. & \multicolumn{1}{c}{ Karakter } & F hitung & KK (\%) \\
\hline 1 & Tinggi tanaman $(\mathrm{cm})$ & $6.65^{* *}$ & 9.2 \\
2 & Panjang batang semu (cm) & $10.23^{* *}$ & 13.55 \\
3 & Panjang daun (cm) & $6.88^{* *}$ & 9.05 \\
4 & Jumlah daun per batang semu & $16.84^{* *}$ & 12.37 \\
5 & Diameter batang semu (mm) & $9.74^{* *}$ & 14.24 \\
6 & Diameter daun (mm) & $8.15^{* *}$ & 10.54 \\
7 & Jumlah suing per rumpun & $65.43^{* *}$ & 23.17 \\
8 & Bobot basah per rumpun (g) & $5.78^{* *}$ & 14.37 \\
9 & Bobot kering per rumpun (g) & $5.92^{* *}$ & 18.66 \\
10 & Tinggi umbi (cm) & $17.15^{* *}$ & 4.71 \\
11 & Diameter umbi (mm) & $8.33^{* *}$ & 12.25 \\
12 & Posisi diameter maksimal (cm) & $2.82^{*}$ & 8.75 \\
13 & Rasio tinggi per diameter umbi & $2.97^{*}$ & 17.55 \\
14 & Lebar leher umbi (mm) & $12.34^{* *}$ & 9.09 \\
15 & Ketebalan kulit umbi kering (mm) & $3.68^{* *}$ & 11.26 \\
\hline
\end{tabular}

Keterangan : $\quad{ }^{*}$ : berpengaruh nyata pada taraf $\alpha=5 \%,{ }^{* *}$ : berpengaruh nyata pada taraf $\alpha=1 \%$.

Tabel 5. Nilai tengah karakter vegetatif tanaman bawang merah

\begin{tabular}{llccccc}
\hline \multicolumn{1}{c}{ Varietas } & $\begin{array}{c}\text { Tinggi } \\
\text { tanaman }(\mathrm{cm})\end{array}$ & $\begin{array}{c}\text { Panjang } \\
\text { batang semu } \\
(\mathrm{cm})\end{array}$ & $\begin{array}{c}\text { Panjang } \\
\text { daun }(\mathrm{cm})\end{array}$ & $\begin{array}{c}\text { Diameter } \\
\text { batang semu } \\
(\mathrm{mm})\end{array}$ & $\begin{array}{c}\text { Diameter } \\
\text { daun }(\mathrm{mm})\end{array}$ & $\begin{array}{c}\text { Jumlah daun } \\
\text { per batang } \\
\text { semu }\end{array}$ \\
\hline Bima (umbi) & $43.3^{\mathrm{abc}}$ & $8.0^{\mathrm{a}}$ & $36.0^{\mathrm{bc}}$ & $5.1^{\mathrm{c}}$ & $4.2^{\mathrm{c}}$ & $6.0^{\mathrm{c}}$ \\
Bima (TSS) & $44.8^{\mathrm{abc}}$ & $4.8^{\mathrm{c}}$ & $40.0^{\mathrm{abc}}$ & $6.7^{\mathrm{bc}}$ & $5.6^{\mathrm{abc}}$ & $6.0^{\mathrm{bc}}$ \\
Pikatan & $41.2^{\mathrm{bc}}$ & $4.5^{\mathrm{c}}$ & $36.7^{\mathrm{bc}}$ & $6.1^{\mathrm{bc}}$ & $4.9^{\mathrm{abc}}$ & $6.0^{\mathrm{bc}}$ \\
Tuk tuk & $38.1^{\mathrm{c}}$ & $4.3^{\mathrm{c}}$ & $33.7^{\mathrm{c}}$ & $5.7^{\mathrm{bc}}$ & $4.5^{\mathrm{c}}$ & $6.0^{\mathrm{bc}}$ \\
Tajuk & $38.9^{\mathrm{c}}$ & $4.3^{\mathrm{c}}$ & $34.6^{\mathrm{c}}$ & $5.8^{\mathrm{bc}}$ & $4.6^{\mathrm{bc}}$ & $6.0^{\mathrm{c}}$ \\
BM 8705 & $52.5^{\mathrm{ab}}$ & $7.1^{\mathrm{ab}}$ & $45.4^{\mathrm{ab}}$ & $8.4^{\mathrm{ab}}$ & $6.3^{\mathrm{a}}$ & $8.0^{\mathrm{b}}$ \\
Sanren & $53.7^{\mathrm{ab}}$ & $6.4^{\mathrm{abc}}$ & $47.2^{\mathrm{ab}}$ & $10.5^{\mathrm{a}}$ & $6.5^{\mathrm{a}}$ & $12.0^{\mathrm{a}}$ \\
Manjung & $51.4^{\mathrm{ab}}$ & $5.6^{\mathrm{bc}}$ & $45.8^{\mathrm{ab}}$ & $8.0^{\mathrm{ab}}$ & $6.2^{\mathrm{ab}}$ & $7.0^{\mathrm{bc}}$ \\
\hline
\end{tabular}

Keterangan: Angka-angka yang diikuti huruf yang sama pada kolom yang sama menunjukkan tidak berbeda nyata pada uji BNJ (Beda Nyata Jujur) taraf 5\% 
dan BM 8705. Varietas Bima (TSS), Pikatan, Tuk tuk, Tajuk, dan Manjung memiliki nilai tengah yang tidak berbeda nyata dengan varietas Bima (umbi).

Nilai tengah hasil pengamatan panjang daun menunjukkan bahwa varietas Sanren memiliki nilai tengah yang berbeda nyata dengan varietas pembanding (Tabel 5). Varietas BM 8705 dan Manjung memiliki nilai tengah yang tidak berbeda nyata varietas pembanding (benih dari umbi). Varietas Pikatan memiliki nilai tengah yang tidak berbeda nyata dengan varietas Bima (umbi). Panjang daun dapat mempengaruhi tingkat kepatahan daun. Umumnya tanaman bawang merah memiliki tipe panjang daun sekitar $30 \mathrm{~cm}$. Panjang daun yang pendek disebabkan oleh faktor lingkungan seperti curah hujan yang tinggi dan faktor genetik (Maizzuddin, 2015).

Hasil pengamatan ketujuh karakter menunjukkan bahwa varietas Sanren merupakan varietas yang memiliki nilai tengah berbeda nyata dengan varietas pembanding, kecuali pada karakter tinggi tanaman dan panjang batang semu. Varietas Pikatan, Tuk tuk, dan Tajuk cenderung memiliki nilai tengah tidak berbeda nyata dengan varietas pembanding untuk karakter-karakter tersebut. Menurut Sumarni dan Rosliani (2010) bahwa proses pertumbuhan bawang merah asal biji dipengaruhi oleh naungan plastik transparan dan tingkat kerapatan tanaman. Penelitian ini dikondisikan pada lingkungan tumbuh yang sama, sehingga adanya keragaman akibat perbedaan varietas yang ditanam.

\section{Komponen Hasil}

Nilai tengah karakter jumlah siung per rumpun berkisar 1.0-8.0 (Tabel 6). Varietas Bima umbi memiliki nilai tengah tertinggi yaitu 8.0. Tujuh varietas lainnya memiliki nilai tengah jumlah siung per rumpun yang tidak berbeda nyata. Keragaan karakter jumlah siung per rumpun masing -masing varietas dapat dilihat pada gambar (Gambar 1).

Karakter bobot basah per rumpun menunjukkan bahwa nilai tengah varietas Manjung berbeda nyata dengan nilai tengah varietas Pikatan dan Tajuk. Varietas Bima umbi, Bima TSS, dan BM 8705 memiliki nilai tengah bobot basah per rumpun yang tidak berbeda nyata. Hasil uji lanjut pada karakter bobot kering per rumpun menunjukkan bahwa nilai tengah varietas Bima (umbi) berbeda nyata dengan varietas Pikatan, Tuk tuk, dan Tajuk. Hasil pengamatan kulit umbi kering menunjukkan nilai tengah yang tidak berbeda nyata pada karakter ketebalan kulit umbi kering dan karakter tingkat melekatnya kulit umbi kering (Tabel 6). Nilai tengah varietas Sanren tidak berbeda nyata dengan varietas lainnya kecuali varietas Bima (umbi).

Hasil pengamatan karakter komponen hasil menunjukkan bahwa nilai tengah tinggi umbi varietas Bima (umbi) terendah (Tabel 7). Varietas BM 8705 dan Manjung memiliki nilai tengah yang berbeda nyata dengan varietas Tajuk dan Bima (umbi). Nilai tengah varietas BM 8705 dan Manjung tidak berbeda nyata dengan varietas Bima (TSS),

Tabel 6. Nilai tengah karakter komponen hasil bawang merah

\begin{tabular}{lcccc}
\hline \multicolumn{1}{c}{ Varietas } & $\begin{array}{c}\text { Jumlah siung } \\
\text { per rumpun }\end{array}$ & $\begin{array}{c}\text { Bobot basah per } \\
\text { rumpun }(\mathrm{g})\end{array}$ & $\begin{array}{c}\text { Bobot kering per } \\
\text { rumpun }(\mathrm{g})\end{array}$ & $\begin{array}{c}\text { Ketebalan kulit } \\
\text { umbi kering }(\mathrm{mm})\end{array}$ \\
\hline Bima (umbi) & $8.00^{\mathrm{a}}$ & $45.00^{\mathrm{abc}}$ & $34.00^{\mathrm{a}}$ & $0.03^{\mathrm{ab}}$ \\
Bima (TSS) & $1.00^{\mathrm{b}}$ & $48.60^{\mathrm{abc}}$ & $24.70^{\mathrm{abc}}$ & $0.04^{\mathrm{a}}$ \\
Pikatan & $1.00^{\mathrm{b}}$ & $36.80^{\mathrm{bc}}$ & $17.70^{\mathrm{c}}$ & $0.04^{\mathrm{ab}}$ \\
Tuk tuk & $1.00^{\mathrm{b}}$ & $33.90^{\mathrm{c}}$ & $19.30^{\mathrm{bc}}$ & $0.04^{\mathrm{ab}}$ \\
Tajuk & $1.00^{\mathrm{b}}$ & $40.20^{\mathrm{bc}}$ & $18.30^{\mathrm{c}}$ & $0.03^{\mathrm{ab}}$ \\
BM 8705 & $2.00^{\mathrm{b}}$ & $51.40^{\mathrm{abc}}$ & $28.30^{\mathrm{abc}}$ & $0.04^{\mathrm{ab}}$ \\
Sanren & $2.00^{\mathrm{b}}$ & $56.10^{\mathrm{ab}}$ & $33.00^{\mathrm{ab}}$ & $0.03^{\mathrm{b}}$ \\
Manjung & $2.00^{\mathrm{b}}$ & $60.30^{\mathrm{a}}$ & $31.30^{\mathrm{abc}}$ & $0.03^{\mathrm{ab}}$ \\
\hline
\end{tabular}

Keterangan : Angka-angka yang diikuti huruf yang sama pada kolom yang sama menunjukkan tidak berbeda nyata pada uji BNJ taraf $\alpha$ $5 \%$
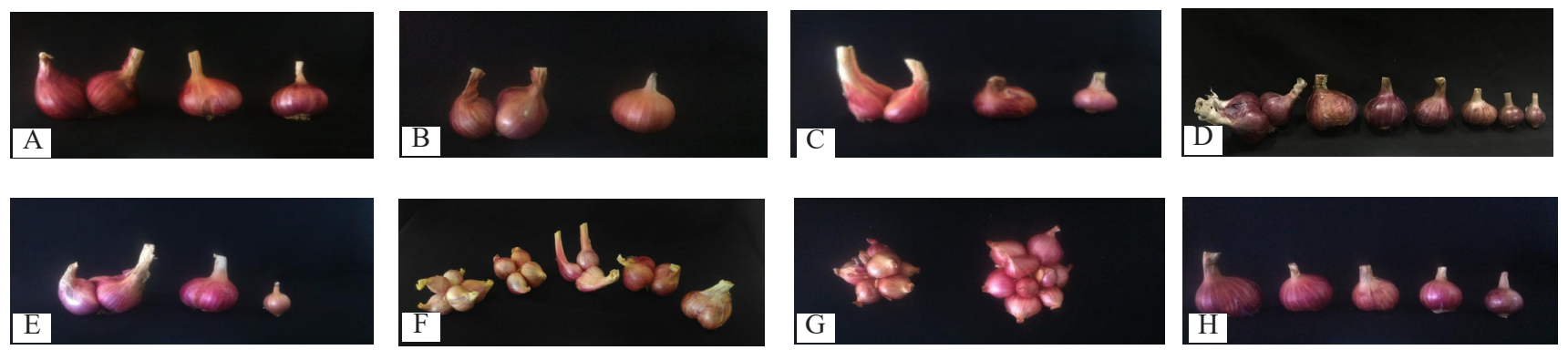

Gambar 1. Keragaan jumlah siung per rumpun beberapa varietas bawang merah yaitu (a) BM 8705, (b) Tuk tuk, (c) Tajuk, (d) Manjung, (e) Pikatan, (f) Sanren, (g) Bima (TSS), (h) Bima umbi 
Pikatan, dan Tuk tuk. Karakter diameter umbi menunjukkan bahwa nilai tengah varietas Bima (umbi) berbeda nyata dengan ketujuh varietas lainnya (Tabel 7). Karakter diameter umbi menunjukkan besar kecilnya umbi yang terbentuk. Hal tersebut berkaitan dengan jumlah umbi yang terbentuk (Gambar 1). Nilai tengah karakter posisi diameter maksimal untuk semua varietas tidak menunjukkan perbedaan yang nyata (Tabel 7). Posisi diameter maksimal berkaitan dengan bentuk penampang membujur umbi (Gambar 1). Varietas Bima (umbi) memiliki nilai tengah rasio tinggi per diameter umbi berbeda nyata dengan varietas Bima (TSS), Sanren dan Manjung. Karakter lebar leher umbi menunjukkan bahwa varietas Bima (umbi) memiliki nilai tengah yang berbeda nyata dengan ketujuh varietas lainnya (Tabel 7). Ketujuh varietas bawang merah TSS memiliki nilai tengah lebar leher umbi yang tidak berbeda nyata, yaitu sekitar 9.3$10.5 \mathrm{~mm}$ atau setara dengan $0.9-1.05 \mathrm{~cm}$.
Hasil pengujian analisis korelasi antar karakter kuantitatif pada bawang merah tersaji dalam Tabel 8 . Karakter tinggi tanaman berkorelasi tidak nyata terhadap karakter jumlah suing per rumpun, tinggi umbi, diameter umbi, dan lebar leher umbi. Karakter tinggi tanaman juga berkorelasi positif sangat nyata terhadap jumlah daun per batang semu, panjang batang semu, diameter batang semu, diameter daun, bobot basah per rumpun, dan bobot kering per rumpun panjang daun. Hal ini menunjukkan bahwa varietas bawang merah TSS dengan nilai tinggi tanaman yang tinggi memiliki kecenderungan nilai jumlah daun per batang semu, panjang batang semu, panjang daun, diameter batang semu, diameter daun, bobot basah per rumpun, dan bobot kering per rumpun yang tinggi.

Bobot kering per rumpun berkorelasi positif sangat nyata terhadap karakter tinggi tanaman, jumlah siung per rumpun, panjang batang semu, panjang daun, diameter

Tabel 7. Nilai tengah karakter kuantitatif pada umbi bawang merah

\begin{tabular}{lccccc}
\hline \multicolumn{1}{c}{ Varietas } & $\begin{array}{c}\text { Tinggi umbi } \\
(\mathrm{cm})\end{array}$ & $\begin{array}{c}\text { Diameter } \\
\text { umbi }(\mathrm{mm})\end{array}$ & $\begin{array}{c}\text { Posisi diameter } \\
\text { maksimal }(\mathrm{cm})\end{array}$ & $\begin{array}{c}\text { Rasio tinggi per } \\
\text { diameter umbi }\end{array}$ & $\begin{array}{c}\text { Lebar leher } \\
\text { umbi }(\mathrm{mm})\end{array}$ \\
\hline Bima (umbi) & $2.4^{\mathrm{d}}$ & $18.6^{\mathrm{b}}$ & $0.9^{\mathrm{b}}$ & $1.3^{\mathrm{a}}$ & $5.1^{\mathrm{b}}$ \\
Bima (TSS) & $3.4^{\mathrm{abc}}$ & $40.3^{\mathrm{a}}$ & $1.2^{\mathrm{ab}}$ & $0.8^{\mathrm{b}}$ & $10.5^{\mathrm{a}}$ \\
Pikatan & $3.2^{\mathrm{abc}}$ & $35.7^{\mathrm{a}}$ & $1.1^{\mathrm{ab}}$ & $0.9^{\mathrm{ab}}$ & $9.4^{\mathrm{a}}$ \\
Tuk tuk & $3.1^{\mathrm{abc}}$ & $34.4^{\mathrm{a}}$ & $1.1^{\mathrm{ab}}$ & $0.9^{\mathrm{ab}}$ & $9.5^{\mathrm{a}}$ \\
Tajuk & $3.1^{\mathrm{c}}$ & $33.5^{\mathrm{a}}$ & $1.1^{\mathrm{ab}}$ & $0.9^{\mathrm{ab}}$ & $9.3^{\mathrm{a}}$ \\
BM 8705 & $3.5^{\mathrm{a}}$ & $38.3^{\mathrm{a}}$ & $1.2^{\mathrm{ab}}$ & $0.9^{\mathrm{ab}}$ & $9.6^{\mathrm{a}}$ \\
Sanren & $3.1^{\mathrm{bc}}$ & $37.3^{\mathrm{a}}$ & $1.1^{\mathrm{ab}}$ & $0.8^{\mathrm{b}}$ & $9.3^{\mathrm{a}}$ \\
Manjung & $3.5^{\mathrm{a}}$ & $41.1^{\mathrm{a}}$ & $1.2^{\mathrm{a}}$ & $0.8^{\mathrm{b}}$ & $10.2^{\mathrm{a}}$ \\
\hline
\end{tabular}

Keterangan : Angka-angka yang diikuti huruf yang sama pada kolom yang sama menunjukkan tidak berbeda nyata pada uji BNJ taraf $\alpha$ $5 \%$

Tabel 8. Korelasi antar karakter kuantitatif bawang merah

\begin{tabular}{|c|c|c|c|c|c|c|c|c|c|c|c|}
\hline & TT & JDBS & PBS & PD & DBS & DD & JSPR & $\mathrm{TU}$ & DU & LLU & BBPR \\
\hline JDBS & $0.762^{* *}$ & & & & & & & & & & \\
\hline PBS & $0.521^{* *}$ & $0.482^{*}$ & & & & & & & & & \\
\hline PD & $0.901^{* *}$ & $0.765^{* *}$ & $0.496^{*}$ & & & & & & & & \\
\hline DBS & $0.809^{* *}$ & $0.947^{* *}$ & $0.376^{\mathrm{tn}}$ & $0.863^{* *}$ & & & & & & & \\
\hline $\mathrm{DD}$ & $0.837^{\text {** }}$ & $0.798^{* *}$ & $0.318^{\mathrm{tn}}$ & $0.888^{* *}$ & $0.933^{* *}$ & & & & & & \\
\hline JSPR & $0.004^{\mathrm{tn}}$ & $0.046^{\mathrm{tn}}$ & $0.697^{* *}$ & $0.102^{\text {tn }}$ & $0.218^{\mathrm{tn}}$ & $0.291^{\mathrm{tn}}$ & & & & & \\
\hline $\mathrm{TU}$ & $0.359^{\text {tn }}$ & $0.260^{\text {th }}$ & $0.296^{\text {tn }}$ & $0.435^{*}$ & $0.473^{*}$ & $0.622^{* *}$ & $-0.799^{* *}$ & & & & \\
\hline $\mathrm{DU}$ & $0.349^{\text {tn }}$ & $0.356^{\mathrm{tn}}$ & $0.304^{\text {tn }}$ & $0.515^{*}$ & $0.592^{* *}$ & $0.698^{* *}$ & $-0.781^{* *}$ & $0.903^{* *}$ & & & \\
\hline LLU & $0.198^{\text {th }}$ & $0.174^{\text {th }}$ & $-0.449^{*}$ & $0.318^{\text {tn }}$ & $0.330^{\text {tn }}$ & $0.461^{*}$ & $-0.799^{* *}$ & $0.759^{* *}$ & $0.762^{* *}$ & & \\
\hline BBPR & $0.694^{* *}$ & $0.496^{*}$ & $0.444^{*}$ & $0.748^{* *}$ & $0.555^{* *}$ & $0.663^{* *}$ & $0.083^{\text {tn }}$ & $0.234^{\mathrm{tn}}$ & $0.261^{\mathrm{tn}}$ & $0.406^{*}$ & \\
\hline BKPR & $0.695^{* *}$ & $0.629^{* *}$ & $0.796^{* *}$ & $0.666^{* *}$ & $0.617^{* *}$ & $0.623^{* *}$ & $0.491^{*}$ & $0.040^{\mathrm{tn}}$ & $0.036^{\mathrm{tn}}$ & $0.162^{\text {tn }}$ & $0.692^{* *}$ \\
\hline
\end{tabular}

Keterangan : $\quad * *=$ berkorelasi sangat nyata; $*=$ berkorelasi nyata, $\mathrm{tn}=$ tidak nyata, $\mathrm{TT}=$ tinggi tanaman, JDBS $=$ jumlah daun per batang semu, PBS = panjang batang semu, PD = panjang daun, DBS = diameter batang semu, DD = diameter daun, JSPR = jumlah suing per rumpun, TU = tinggi umbi, DU = diameter umbi, LLU = lebar leher umbi, BBPR = bobot basah per rumpun, $\mathrm{BKPR}=$ bobot kering per rumpun 
batang semu, diameter daun, dan bobot basah per rumpun. Hal ini menunjukkan bahwa varietas bawang merah dengan nilai bobot kering per rumpun yang besar memiliki kecenderungan nilai tinggi tanaman, jumlah siung per rumpun, panjang batang semu, panjang daun, diameter batang semu, diameter daun, dan bobot basah per rumpun yang tinggi. Karakter bobot kering per rumpun berkorelasi nyata terhadap jumlah daun per batang semu. Karakter bobot kering per rumpun berkorelasi tidak nyata terhadap karakter tinggi umbi, diameter umbi, dan lebar leher umbi. Hal tersebut menerangkan bahwa karakter jumlah siung per rumpun mempengaruhi nilai bobot basah per rumpun.

\section{KESIMPULAN}

Terdapat keragaman pada karakter warna dan bentuk umbi pada tujuh varietas bawang merah TSS. Varietas Sanren mempunyai nilai panjang daun, diameter batang semu, diameter daun, dan jumlah daun per batang semu yang lebih tinggi dibandingkan dengan varietas pembanding (Bima, benih dari umbi). Berdasarkan nilai bobot kering per rumpun pada rerata varietas, varietas Sanren, Manjung, dan BM 8705 tidak berbeda nyata dengan varietas pembanding (Bima, benih dari umbi). Berdasarkan hasil analisis korelasi, karakter bobot kering per rumpun berkorelasi nyata dengan karakter tinggi tanaman, jumlah siung per rumpun, panjang batang semu, panjang daun, diameter batang semu, diameter daun, bobot basah per rumpun, dan jumlah siung per rumpun.

\section{DAFTAR PUSTAKA}

Anwar, A., Sudarsono, S. Ilyas. 2005. Perbenihan sayuran di Indonesia : kondisi terkini dan prospek bisnis benih sayuran. Buletin Agronomi. 33(1): 38-47.

Aziz, H.A., A. Ete, Bahrudin. 2013. Karakterisasi sumber benih bawang merah dari berbagai daerah sentra produksi di Lembah Palu. e-J. Agrotekbis. 1(3):221227.

Azmi, C., I.M. Hidayat, G. Wiguna. 2011. Pengaruh varietas dan ukuran umbi terhadap produktivitas bawang merah. Jurnal Hortikultura. 21(3): 206-213

Basuki, R.S. 2009. Analisis kelayakan teknis dan ekonomis teknologi budidaya bawang merah dengan benih biji botani dan benih umbi tradisional. J. Hort. 19(2): 214-227.

Darma, W.A. 2015. Alternatif bahan tanam selain umbi pada budidaya bawang merah (Allium ascolonicum L.). Tesis. Sekolah Pascasarjana. Institut Pertanian Bogor. Bogor.

Firmansyah, M.A., A. Anto. 2013. Teknologi budidaya bawang merah lahan marginal diluar musim. Kantor Perwakilan Bank Indonesia, Palangkaraya.
Firmansyah, M. A., D. Musaddad, T. Liana, M.S. Mokhtar, M.P. Yufdi. 2014. Uji adaptasi bawang merah di lahan gambut pada saat musim hujan di Kalimantan Tengah. J. Hort. 24(2): $114-123$.

Hilman Y., R. Rosliani, E.R. Palupi. 2014. Pengaruh ketinggian tempat terhadap pembungaan, produksi, dan mutu benih botani bawang merah. J. Hort. 24(2): $154-161$.

[Kementan] Kementrian Pertanian. 2013. Teknologi bawang merah Off- Season: strategi dan implementasibudidaya.http://hortikultura.litbang. pertanian.go.id/Buku_Inovasi/2130.Suwandi\%20 Teknologi\%20off\%20season.pdf. [23 Maret 2017].

[Kementan] Kementrian Pertanian. 2016. Petunjuk Teknis (Juknis) Proliga Bawang Merah 40 ton/ha Asal TSS (= True Shallot Seed). Pusat Penelitian dan Pengembangan Pertanian. Kementrian Pertanian. http://sumbar.litbang.pertanian.go.id/images/pdf/ JUKNIS-PROLIGA.pdf. [20 Oktober 2017].

Muizzuddin, M.I. 2015. Karakterisasi 20 genotipe bawang merah (Allium cepa L.). Skripsi. Fakultas Pertanian. Institut Pertanian Bogor. Bogor.

Palupi, E.R., R. Rosliani, Y. Hilman. 2015.Peningkatan produksi dan mutu benih botani bawang merah (True Shallot Seed) dengan introduksi serangga penyerbuk. J. Hort. 25(1): 15-25.

Pangestuti, R., E. Sulistyaningsih. 2011. Potensi penggunaan true shllot seed (TSS) sebagai sumber benih bawang merah di Indonesia. Dalam Prosiding Semiloka Nasional "Dukungan Agro-Inovasi untuk Pemberdayaan Petani, Kerjasama UNDIP, BPTP Jateng, dan Pemprov Jateng". Balai Pengkajian Teknologi Pertanian Jawa Tengah. Jawa Tengah.

[PPVTPP] Pusat Perlindungan Varietas Tanaman dan Perizinan Pertanian. 2016. Panduan pengujian pelaksanaan uji (PPU) kebaruan, keunikan, keseragaman, dan kestabilan bawang merah (Allium ascolonicum L.). PVT/PPU/23/1.

Prayudi, B., P. Retno, C.K. Aryana. 2015. Produksi umbi mini bawang merah asal True Shallot Seed (TSS). Balai Pengkajian Teknologi Pertanian Jawa Tengah. Badan Penelitian dan Pengembangan Pertanian. Kementrian Pertanian.

[Pusdatin] Pusat Data dan Sistem Informasi Pertanian. 2016. Outlook komoditas pertanian sub sektor hortikultura bawang merah. Epublikasi.pertanian.go.id/arsipoutlook/76-outlook-hortikultura/426-outlookbawang-merah-2016.pdf. [25 Mei 2018]. 
Puspitasari, A.M. Kiloes, A. Sulistyaningrum. 2016. Analisis kelayakan teknis produksi benih bawang merah TSS (True Seed of Shallot). Dalam Seminar Nasional Technopreneurship dan Alih Teknologi. 2(1) : 73-81.

Robinowitch, H.D., R. Kamenetsky. 2002. Shallot (Allium cepa, Aggregatum Group). In Robinowitch H.D. dan L. Currah, (Ed). Allium Crop Science: Recent Advances. CAB International, Wallingford, UK.

Rosliani, R. 2013. Peningkatan produksi dan mutu benih botani (True Shallot Seed) bawang merah (Allium cepa var. ascolonicum) dengan BAP dan boron, serta serangga penyerbuk. Tesis. Institut Pertanian Bogor. Bogor.

Sakinah, F. 2013. Analisis pengaruh faktor cuaca untuk prediksi serangan organisme pengganggu tanaman (OPT) pada tanaman bawang merah. Skripsi. Fakultas Pertanian. Institut Pertanian Bogor. Bogor.

Stasiun Klimatologi Bogor Data Iklim Desember 2017Maret 2018. Stasiun Klimatologi Bogor dan Pos Hujan Pacet, Bogor.

Sumarni, N., A. Hidayat. 2005. Budidaya Bawang Merah. Balai Penelitian Tanaman Sayuran, Bandung.
Sumarni, N., R. Rosliani. 2010. Pengaruh naungan plastik transparan, kerapatan tanaman, dan dosis $\mathrm{N}$ terhadap produksi umbi bibit asal biji bawang merah. J. Hort. 20(1): $52-59$.

Syukur, M., S. Sujiprihati, R. Yunianti. 2015. Teknik Pemuliaan Tanaman. Penebar Swadaya, Jakarta.

Tanjung, M.H. 2016. Budidaya dan pengendalian organisme pengganggu tanaman bawang merah (Allium ascolonicum) di Brebes, Jawa Tengah. Skripsi. Institut Pertanian Bogor. Bogor.

[UF] University Farm. 2018. Profil Unit Lapangan Pasir Sarongge. Uf.ipb.ac.id/index.php/pasir-sarongge.[31 Januari 2018].

Wulandari, A., D. Purnomo, Supriyono. 2014. Potensi biji botani bawang merah (True Shallot Seed) sebagai bahan tanam budidaya bawang merah di Indonesia. Jurnal EL - VIVO. 2(1): 28 - 36.

Widajati E., E. Murniati, E.R. Palupi, T. Kartika, M.R. Suhartanto, A. Qadir. 2013. Dasar Ilmu Teknologi Benih. IPB Press, Bogor. 